\title{
Model Pelindungan Hukum Terhadap Justice Collaborator Tindak Pidana Korupsi Di Indonesia*
}

\author{
Dwi Oktafia Ariyanti dan Nita Ariyani \\ Fakultas Hukum Universitas Janabadra \\ Jl. Timoho II No. 40 Kota Yogyakarta \\ dwi_oktafia@janabadra.ac.id, nita_ariyani@janabadra.ac.id
}

Received: 16 November 2019; Accepted: 3 Maret 2020; Published: 25 Agustus 2020

DOI: 10.20885 /iustum.vol27.iss2.art6

\begin{abstract}
The issue in this research is the regulation of legal protection against justice collaborators of corruption in Indonesia which is not optimal, and the absence of an appropriate protection model for optimum efforts of protection for justice collaborators in handling corruption in Indonesia. This needs to be studied because the role of justice collaborator is very much needed to disclose major cases such as corruption, whereas his testimony can pose a large risk that must be borne by the justice collaborator, hence legal protection for justice collaborators is crucial. The method in this study uses a type of juridical normative research that is focused on studying the norms of positive law. This research concludes, first, the regulations regarding the protection of justice collaborators are listed in various regulations, but there are no specific, clear and firm regulations regarding protection and procedural arrangements for determining a justice collaborator. Thus an appropriate legal protection model is needed to optimize protection for justice collaborators in criminal acts of corruption in order to fill the legal vacuum. Second, the legal protection model for justice collaborators in handling corruption in Indonesia can utilise a persuasive protection model.
\end{abstract}

Key Words : Corruption; justice collaborator; legal protection

Abstrak

Permasalahan dalam penelitian ini adalah mengenai pengaturan pelindungan hukum terhadap justice collaborator tindak pidana korupsi di Indonesia yang belum optimal, dan belum adanya model pelindungan yang tepat bagi upaya pelindungan yang optimal bagi justice collaborator dalam penanganan tindak pidana korupsi di Indonesia. Hal tersebut perlu dikaji karena peranan justice collaborator sangat dibutuhkan untuk pengungkapan perkara besar seperti tindak pidana korupsi, sedangkan dari kesaksiannya tersebut dapat menimbulkan resiko besar yang harus ditanggung oleh seorang justice collaborator, maka sangat diperlukan adanya pelindungan hukum bagi justice collaborator. Metode dalam penelitian ini menggunakan tipe penelitian yuridis normatif penelitian yang difokuskan untuk mengkaji kaidah-kaidah atau norma-norma dalam hukum positif. Penelitian ini menyimpulkan, pertama, pengaturan mengenai pelindungan terhadap justice collaborator tercantum di berbagai peraturan, namun belum ada peraturan yang mengatur secara khusus, jelas dan tegas mengenai pengaturan pelindungan dan prosedural penetapan sebagai seorang justice collaborator. Maka diperlukan model pelindungan hukum yang tepat untuk mengoptimalkan pelindungan bagi justice collaborator tindak pidana korupsi guna mengisi kekosongan hukum. Kedua, model pelindungan hukum terhadap justice collaborator dalam penanganan tindak pidana korupsi di Indonesia dapat menggunakan model pelindungan persuasif.

Kata-kata Kunci : Justice collaborator; pelindungan hukum; tindak pidana korupsi

* Hibah Penelitian Dosen Pemula Kemenristekdikti 2019 


\section{Pendahuluan}

Korupsi merupakan suatu perbuatan yang dapat merusak kehidupan berbangsa dan bernegara. Tindak pidana korupsi yang semakin meluas dan sistematis juga merupakan pelanggaran terhadap hak sosial dan hak ekonomi masyarakat. Tindak pidana korupsi oleh karenanya tidak dapat dikategorikan hanya sebagai kejahatan biasa melainkan suatu kejahatan yang luar biasa (extra ordinary crime).

Para penegak hukum sering mengalami kesulitan dalam mengungkap pelaku tindak pidana korupsi karena perkara-perkara tindak pidana korupsi dilakukan secara terorganisir dan pelakunya lebih dari satu orang. Pengungkapan perkara tindak pidana korupsi ini tentu membutuhkan keberanian yang cukup besar dan adanya saksi yang mengetahui bahkan terlibat secara langsung maupun tidak langsung dalam perkara tersebut. Mengingat resikonya yang begitu besar, maka sedikit orang yang berani bersedia menjadi saksi dalam perkara tindak pidana korupsi. Saksi yang mengetahui secara langsung dan terlibat secara langsung dalam kasus dan berani melaporkan kejadian tersebut dikenal dengan istilah saksi pelaku yang bekerjasama dengan penegak hukum, atau disebut "justice collaborator".

Seorang pelaku yang bekerjasama (justice collaborator) merupakan salah satu pelaku tindak pidana tertentu, mengakui kejahatan yang dilakukannya, bukan pelaku utama dalam kejahatan tersebut serta memberikan keterangan sebagai saksi di dalam proses peradilan. ${ }^{1}$ Titik tolak ide perkembangan mengenai justice collaborator adalah ketentuan Pasal 37 ayat (2) United Nations Convention Against Corruption (UNCAC) 2003 yang telah diratifikasi Indonesia melalui Undang-Undang Nomor 7 Tahun 2006 tentang Pengesahan United Nations Convention Against Corruption (Konvensi Perserikatan Bangsa-Bangsa Anti Korupsi 2003).

Perangkat hukum yang tersedia untuk memberikan pelindungan terhadap justice collaborator secara implisit tercantum dalam KUHAP, dan Undang-Undang Nomor 13 Tahun 2006 tentang Pelindungan Saksi dan Korban yang kini telah diubah dengan Undang-Undang Nomor 31 Tahun 2014 tentang Perubahan Atas

1 Lilik Mulyadi, “Whistleblower dan Justice Collaborator Dalam Upaya Penanggulangan Organized Crime”, PT Alumni, Bandung, 2015, hlm. 1. 
Undang-Undang Nomor 13 Tahun 2006 tentang Pelindungan Saksi dan Korban. Serta kemudian diikuti dengan Surat Edaran Mahkamah Agung Nomor 04 Tahun 2011 tentang Perlakuan terhadap Pelapor Tindak Pidana (whistleblower) dan Saksi Pelaku yang Bekerja Sama (justice collaborator) di dalam Perkara Tindak Pidana Tertentu.

Justice collaborator dalam perkembangannya perlu mendapatkan perhatian yang serius karena mereka memiliki peran kunci dalam pengungkapan tindak pidana korupsi yang sulit diungkap oleh penegak hukum. Peran kunci yang dimiliki oleh justice collaborator tersebut diantaranya, untuk mengungkap suatu tindak pidana atau akan terjadinya suatu tindak pidana, sehingga pengembalian aset dari hasil suatu tindak pidana bisa dicapai kepada negara, memberikan informasi kepada aparat penegak hukum, dan memberikan kesaksian dalam proses peradilan. ${ }^{2}$ Besarnya sumbangsih yang dapat diberikan oleh justice collaborator kepada penegak hukum dalam pengungkapan tindak pidana korupsi perlu disertai pelindungan yang optimal terhadap justice collaborator.

Pelindungan terhadap justice collaborator dipenuhi dengan berbagai tantangan, di tengah minimnya pelindungan hukum yang ada. Sebagai contoh terdakwa Abdul Khoir dalam kasus suap proyek infrastruktur Kementerian PUPR di Maluku. Penuntut umum KPK semula menuntut terdakwa dengan pidana penjara 2 tahun 6 bulan, akan tetapi majelis hakim justru menjatuhkan pidana terhadap terdakwa melampaui tuntutan jaksa, yakni dengan pidana penjara 4 tahun. Penyidik telah menetapkan terdakwa Abdul Khoir sebagai justice collaborator dan penuntut umum dalam tuntutannya telah pula memohonkan agar penetapan justice collaborator tersebut dipertimbangkan oleh majelis hakim sebagai hal yang meringankan hukuman bagi terdakwa.

Majelis hakim berpegangan pada SEMA Nomor 04 Tahun 2011 tentang Perlakuan terhadap Pelapor Tindak Pidana (whistleblower) dan Saksi Pelaku yang Bekerja Sama (justice collaborator) di dalam Perkara Tindak Pidana Tertentu. Menurut SEMA tersebut, seseorang dapat dikualifikasikan sebagai justice collaborator apabila pelaku bukanlah pelaku utama, namun dalam konteks kasus

2 https://business-law.binus.ac.id/2018/02/14/justice-collaborator-dan-pelindungan-hukumnya, diunggah tanggal 14 Februari 2018, diakses tanggal 19 Januari 2020 
ini hakim menganggap terdakwa adalah pelaku utama dalam tindak pidana yang dilakukan. Ada perbedaan penilaian dalam konteks kasus ini, antara penyidik dan penuntut umum dengan hakim dalam menentukan seseorang tersebut dikategorikan sebagai justice collaborator atau tidak.

Persoalan mengenai kualifikasi justice collaborator dalam konteks formulasi serta praktiknya masih menimbulkan dilema. Serta jika ditinjau dari sistem peradilan pidana Indonesia, pada tahap apa seseorang dapat disebut sebagai justice collaborator, apakah dari tingkat penyidikan, penuntutan, peradilan ataukah kolaborasi pada semua tingkat sistem tersebut. Selain itu juga pada tataran penerapannya masih ada kekurangan dalam konteks pelindungan hukum bagi seorang justice collaborator.

\section{Rumusan Masalah}

Atas dasar latar belakang yang telah dipaparkan di atas, maka dapat ditentukan rumusan permasalahan yang layak dikaji yaitu: pertama, bagaimana problematik pengaturan pelindungan hukum bagi justice collaborator yang memicu pelaku enggan mengajukan diri sebagai justice collaborator dalam perkara tindak pidana korupsi di Indonesia? Kedua, bagaimana model pelindungan yang tepat untuk melindungi justice collaborator dalam penanganan perkara tindak pidana korupsi di Indonesia?

\section{Tujuan Penelitian}

Tujuan dalam penelitian ini untuk: pertama, menganalisis problematik pengaturan pelindungan hukum terhadap justice collaborator yang memicu pelaku enggan mengajukan diri sebagai justice collaborator dalam penanganan perkara tindak pidana korupsi di Indonesia; kedua, merumuskan model pelindungan yang tepat diberikan kepada justice collaborator dalam penanganan tindak pidana korupsi di Indonesia.

\section{Metode Penelitian}

Penelitian menggunakan tipe penelitian yuridis normatif. Metode pendekatan yang digunakan adalah pendekatan perundang-undangan (statute approach) untuk mengetahui kesesuaian, konsistensi dan sejarah pelindungan 
hukum terhadap justice collaborator tindak pidana korupsi. ${ }^{3}$ Serta pendekatan analitis (analytical approach) untuk menelaah makna istilah hukum yang digunakan dalam praktik hukum, serta pengertian, asas, kaidah dan konsep hukum.

Sumber data yang digunakan adalah data sekunder yang terdiri dari bahan hukum primer berupa Undang-Undang Dasar Negara Republik Indonesia Tahun 1945, Kitab Undang-Undang Hukum Pidana dan peraturan perundang-undangan yang terkait dengan pelindungan hukum terhadap justice collaborator tindak pidana korupsi. Serta, bahan hukum sekunder meliputi buku-buku literatur, jurnal ilmiah, putusan pengadilan, artikel-artikel, makalah-makalah, hasil-hasil penelitian dan sumber informasi dari internet yang berkaitan dengan pelindungan hukum terhadap justice collaborator tindak pidana korupsi.

Data yang diperoleh dianalisa dengan menggunakan metode kualitatif. Cara pengolahan bahan hukum dilakukan secara deduktif yakni menarik kesimpulan dari suatu permasalahan yang bersifat umum terhadap permasalahan yang konkrit berkaitan dengan pelindungan hukum terhadap justice collaborator tindak pidana korupsi di Indonesia.

\section{Hasil Penelitian dan Pembahasan}

\section{Pengaturan Pelindungan Hukum Terhadap Justice Collaborator Tindak Pidana} Korupsi di Indonesia

Tindak pidana korupsi merupakan perbuatan curang yang menimbulkan kerugiaan negara, atau merupakan penyelewengan, penggelapan uang negara yang diperuntukan untuk kepentingan pribadi atau golongan. ${ }^{4}$ Tindak pidana korupsi masuk ke dalam kejahatan yang luar biasa atau extra ordinary crime dan mempunyai permasalahan yang lebih rumit jika dibandingkan dengan tindak pidana khusus lainnya. Terutama dalam tahap penyidikan, ada beberapa lembaga yang memiliki kewenangan dalam penyidikan tindak pidana korupsi. ${ }^{5}$

Karena sifatnya yang luar biasa tersebut maka membutuhkan penanganan yang luar biasa pula. Pengungkapan tindak pidana korupsi yang sulit dilakukan karena tindak pidana korupsi seringkali dilakukan secara sistematis dan

\footnotetext{
${ }^{3}$ Peter Mahmud Marzuki, Penelitian Hukum, Edisi Revisi, Prenadamedia Group, Jakarta, 2014, hlm. 136.

${ }^{4}$ Aziz Syamsuddin, Tindak Pidana Khusus, Sinar Grafika, Jakarta, 2011, hlm. 15. hlm. 323.

5 Ifrani, "Tindak Pidana Korupsi Sebagai Kejahatan Luar Biasa", Al'Adl Vol. 9 No. 3, Desember 2017,
} 
melibatkan lebih dari satu orang serta pelaku yang terlibat merupakan seseorang yang memiliki kelas ekonomi yang tinggi, kewenangan dan kekuasaan politik, maka para penegak hukum membutuhkan seseorang yang dapat memberikan kesaksiaannya dan mengetahui secara pasti tindak pidana korupsi yang terjadi.

Justice collaborator disebut sebagai seorang pelaku tindak pidana yang telah memberikan bantuan sebagai saksi kepada penegak hukum dalam pengungkapan suatu tindak pidana dimana dia terlibat dalam tindak pidana tersebut. ${ }^{6}$ Pelindungan hukum terhadap keberadaan justice collaborator perlu mendapatkan perhatian yang serius mengingat pentingnya peranan seorang justice collaborator khususnya dalam pengungkapan perkara tindak pidana korupsi.

Pelindungan terhadap justice collaborator tercantum dalam Pasal 10 dan Pasal 10A Undang-Undang Nomor 13 Tahun 2006 yang kini telah diubah menjadi Undang-Undang Nomor 31 Tahun 2014 tentang Perubahan Atas Undang-Undang Nomor 13 Tahun 2006 tentang Pelindungan Saksi dan Korban. Pasal 10 UU a quo menentukan sebagai berikut:

(1) Saksi, Korban, Saksi Pelaku, dan/atau Pelapor tidak dapat dituntut secara hukum, baik pidana maupun perdata atas kesaksian dan/atau laporan yang akan, sedang, atau telah diberikannya, kecuali kesaksian atau laporan tersebut diberikan tidak dengan iktikad baik. (2) Dalam hal terdapat tuntutan hukum terhadap Saksi, Korban, Saksi Pelaku, dan/atau Pelapor atas kesaksian dan/atau laporan yang akan, sedang, atau telah diberikan, tuntutan hukum tersebut wajib ditunda hingga kasus yang ia laporkan atau ia berikan kesaksian telah diputus oleh pengadilan dan memperoleh kekuatan hukum tetap." ${ }^{\prime 7}$

Sementara Pasal 10A UU a quo menentukan bahwa:

(1) Saksi Pelaku dapat diberikan penanganan secara khusus dalam proses pemeriksaan dan penghargaan atas kesaksian yang diberikan. (2) Penanganan secara khusus sebagaimana dimaksud pada ayat (1) berupa: a. pemisahan tempat penahanan atau tempat menjalani pidana antara Saksi Pelaku dengan tersangka, terdakwa, dan/atau narapidana yang diungkap tindak pidananya; b. pemisahan pemberkasan antara berkas Saksi Pelaku dengan berkas tersangka dan terdakwa dalam proses penyidikan, dan penuntutan atas tindak pidana yang diungkapkannya; dan/atau c. memberikan kesaksian di depan persidangan tanpa berhadapan langsung dengan terdakwa yang

\footnotetext{
hlm. 444.

${ }^{6}$ Hariman Satria, "Menakar Pelindungan Justice Collaborator", Jurnal Konstitusi Vol. 13 No. 2, Juni 2016,

7 Pasal 10 Undang-Undang Nomor 31 Tahun 2014 tentang Perubahan Atas Undang-Undang Nomor 13 Tahun 2006 tentang Pelindungan Saksi dan Korban.
} 
diungkap tindak pidananya. (3) Penghargaan atas kesaksian sebagaimana dimaksud pada ayat (1) berupa: a. keringanan penjatuhan pidana; atau $b$. pembebasan bersyarat, remisi tambahan, dan hak narapidana lain sesuai dengan ketentuan peraturan perundang-undangan bagi Saksi Pelaku yang berstatus narapidana. (4) Untuk memperoleh penghargaan berupa keringanan penjatuhan pidana sebagaimana dimaksud pada ayat (3) huruf a, LPSK memberikan rekomendasi secara tertulis kepada penuntut umum untuk dimuat dalam tuntutannya kepada hakim. (5) Untuk memperoleh penghargaan berupa pembebasan bersyarat, remisi tambahan, dan hak narapidana lain sebagaimana dimaksud pada ayat (3) huruf b, LPSK memberikan rekomendasi secara tertulis kepada menteri yang menyelenggarakan urusan pemerintahan di bidang hukum." ${ }^{\prime 8}$

Pasal 37 ayat (2) UNCAC Tahun 2003 sebagaimana telah diratifikasi dengan Undang-Undang Nomor 7 Tahun 2006 menyebutkan bahwa setiap negara peserta harus memastikan dalam sistem hukumnya ketentuan tentang pengurangan hukuman bagi terdakwa yang bekerjasama dalam penyelidikan dan penuntutan kejahatan yang ditetapkan dalam konvensi. 9

Surat Edaran Mahkamah Agung Nomor 04 Tahun 2011 tentang Perlakuan Bagi Pelapor Tindak Pidana (whistleblower) dan Saksi Pelaku yang Bekerja Sama (justice collaborator) di dalam Perkara Tindak Pidana Tertentu, mengatur mengenai pedoman untuk menentukan seseorang sebagai justice collaborator serta pertimbangan hakim dalam penentuan pidana yang akan dijatuhkan. Hakim wajib mempertimbangkan rasa keadilan dalam pemberian perlakuan khusus dalam bentuk keringanan pidana yang akan diberikan kepada justice collaborator. ${ }^{10}$

Pasal 5 ayat (2) Peraturan Pemerintah Nomor 71 Tahun 2000 tentang Tata Cara Pelaksanaan Peran Serta Masyarakat dan Pemberian Penghargaan Dalam Pencegahan dan Pemberantasan Tindak Pidana Korupsi mengatur mengenai hak dan pelindungan bagi setiap saksi dan pelapor, dan apabila ternyata dari hasil penyelidikan dan penyidikan terdapat cukup bukti yang memperkuat keterlibatan yang bersangkutan dalam tindak pidana korupsi, maka terhadapnya

\footnotetext{
8 Pasal 10 A, Undang-Undang Nomor 31 Tahun 2014 tentang Perubahan Atas Undang-Undang Nomor 13 Tahun 2006 tentang Pelindungan Saksi dan Korban.

${ }_{9}$ Pasal 37 ayat (2) United Nations Convention Against Corruption, 2003 (Konvensi Perserikatan Bangsa-Bangsa Anti Korupsi, 2003

10 Surat Edaran Mahkamah Agung Nomor 04 Tahun 2011 tentang Perlakuan terhadap Pelapor Tindak Pidana (whistleblower) dan Saksi Pelaku yang Bekerja Sama (justice collaborator) di Dalam Perkara Tindak Pidana Tertentu
} 
tidak diberikan pelindungan status hukum tapi tetap diberikan pelindungan dalam proses pemeriksaan peradilan. ${ }^{11}$

Pasal 41 ayat (2) huruf e Undang-Undang Nomor 31 Tahun 1999 tentang Pemberantasan Tindak Pidana Korupsi menyatakan masyarakat yang berperan serta membantu upaya pencegahan dan pemberantasan tindak pidana korupsi berhak mendapat pelindungan hukum. ${ }^{12}$ Sementara Undang-Undang Nomor 8 Tahun 1981 tentang Kitab Undang-Undang Hukum Acara Pidana (KUHAP) mengatur mengenai pelindungan saksi mahkota. Saksi mahkota adalah istilah yang diberikan kepada seseorang terdakwa yang menjadi saksi dalam mengungkapkan peristiwa pidana yang dilakukannya. ${ }^{13}$ KUHAP yang merupakan salah satu pencapaian dalam bidang hukum di Indonesia, telah mencantumkan ketentuan pelindungan terhadap hak-hak asasi tersangka atau terdakwa. ${ }^{14}$ Meski demikian, KUHAP belum secara eksplisit mengatur pelindungan hukum bagi justice collaborator.

Sejauh ini peraturan yang mengatur secara eksplisit mengenai pelindungan terhadap justice collaborator hanya terdapat di dalam Undang-Undang Nomor 13 Tahun 2006 sebagaimana telah diubah menjadi Undang-Undang Nomor 31 Tahun 2014 tentang Perubahan Atas Undang-Undang Nomor 13 Tahun 2006 tentang Pelindungan Saksi dan Korban, serta Surat Edaran Mahkamah Agung Nomor 04 Tahun 2011 tentang Perlakuan Bagi Pelapor Tindak Pidana (whistleblower) dan Saksi Pelaku yang Bekerja Sama (justice collaborator) di dalam Perkara Tindak Pidana Tertentu.

Meskipun pelindungan terhadap justice collaborator telah diatur di dalam Undang-Undang Nomor 31 Tahun 2014, namun undang-undang a quo hanya mengatur mengenai penanganan khusus dalam proses pemeriksaan terhadap justice collaborator yang terpisah dengan tersangka, terdakwa dan/atau terpidana yang diungkap tindak pidananya, serta pemberian penghargaan atas kesaksian

\footnotetext{
11 Peraturan Pemerintah Nomor 71 Tahun 2000 tentang Tata Cara Pelaksanaan Peran Serta Masyarakat dan Pemberian Penghargaan Dalam Pencegahan dan Pemberantasan Tindak Pidana Korupsi.

12 Undang-Undang Nomor 31 Tahun 1999 kini telah diubah menjadi Undang-Undang Nomor 20 Tahun 2001 tentang Pemberantasan Tindak Pidana Korupsi.

13 Achmad Saifudin Firdaus, "Kedudukan Terdakwa Sebagai Saksi (Saksi Mahkota) Terhadap Terdakwa Lain Dalam Tinjauan Hukum Acara Pidana, Lex Jurnalica Vol. 12 No. 3, Desember 2015, hlm. 226.

${ }^{14}$ Teguh Sulistia, Hukum Pidana Horizon Pasca Reformasi, PT. Raja Grafindo Persada, Jakarta, 2011, hlm. 9
} 
yang diberikan. Pemberian penghargaan ini berupa keringanan penjatuhan pidana maupun berupa pembebasan bersyarat, remisi tambahan dan hak narapidana lainnya.

Justice collaborator baru bisa menerima penghargaan dengan terlebih dahulu harus mendapat rekomendasi secara tertulis dari Lembaga Pelindungan Saksi dan Korban (LPSK) yang nantinya akan diberikan kepada penegak hukum yang menangani proses hukum tersebut. Keberhasilan dalam tahap pemeriksaan perkara pidana akan memengaruhi berhasil tidaknya pemerikasaan di sidang pengadilan nantinya. ${ }^{15}$ Maka perlu adanya kerja keras dari para penegak hukum dalam penanganan tindak pidana dan penentuan dapat tidaknya seseorang menjadi justice collaborator.

Penjelasan di atas menggambarkan bahwa masih ada kelemahan pengaturan, yakni belum jelasnya pengajuan permohonan justice collaborator ke LPSK. Apabila tersangka ditahan oleh KPK, apakah pemohonan sebagai seorang justice collaborator akan diajukan kepada KPK atau LPSK atau kepada kedua lembaga tersebut. Hal ini menjadi persoalan dalam tataran implementasinya.

Ada beberapa kemungkinan jawaban dari permasalahan tersebut. Pertama, permohonan sebagai justice collaborator dapat diajukan kepada KPK. Kedua, untuk mendapatkan penanganan khusus tergantung dari lembaga yang menangani proses tindak pidana tersebut, penilaian mengenai tersangka atau terdakwa dapat atau tidaknya dijadikan sebagai justice collaborator ditentukan oleh lembaga yang bersangkutan. Ketiga, penghargaan untuk mendapatkan keringanan hukuman yang telah mendapatkan surat rekomendasi dari LPSK belum tentu dapat dijadikan sebagai dasar keringanan hukuman karena surat rekomendasi tersebut tidak mengikat hakim dalam memberikan pertimbangan putusannya. ${ }^{16}$

Seharusnya pengaturan mengenai justice collaborator dimasukkan dalam revisi KUHAP, karena KUHAP merupakan instrumen hukum pidana formil yang menentukan prosedural pemeriksaan perkara dalam sistem peradilan pidana (criminal justice system) di Indonesia. LPSK dikarenakan tidak masuk dalam sistem

\footnotetext{
15 Yahya Harahap, Pembahasan, Permasalahan dan Penerapan KUHAP, Penyidikan dan Penuntutan, Edisi Kedua, Sinar Grafika, Jakarta, 2012, hlm. 109.

16 Muhammad Iqbal Lubis, "Pelindungan Hukum Terhadap Justice Collaborator Dalam Hukum Pidana di Indonesia : Analisis Putusan Mahkamah Agung No. 2223K/Pid.Sus/2012", USU Law Journal Vol. 7 No. 3, Juni 2019, hlm. 61.
} 
peradilan pidana, memicu rekomendasi yang dikeluarkannya kurang mendapat pertimbangan dari penegak hukum, karena memiliki dua pilihan yaitu boleh dipertimbangkan atau boleh tidak dipertimbangkan. ${ }^{17}$

Pengaturan pelindungan hukum bagi justice collaborator perlu dimasukkan dalam revisi KUHAP. Hal ini karena banyaknya lembaga yang berwenang menerima dan menangani laporan dari seorang justice collaborator. Diperlukan penegasan kewenangan, fungsi dan tugas yang dimiliki masing-masing lembaga dalam prosedur penanganan dan pemberian pelindungan terhadap justice collaborator melalui revisi KUHAP. Apabila ketentuan tersebut masuk dalam revisi KUHAP maka dapat menjadi pedoman dan dasar-dasar yang kokoh bagi para penegak hukum dalam memberikan pelindungan terhadap justice collaborator, mengingat KUHAP merupakan pedoman formal yang mengikat dan bersifat imperatif bagi lembaga penegak hukum.

Penilaian penuntut umum dalam tuntutannya dapat digolongkan sebagai justice collaborator atau tidak, selama ini berpegang pada Surat Edaran Mahkamah Agung Republik Indonesia (SEMA RI) Nomor 4 Tahun 2011 tentang Perlakuan bagi Pelapor Tindak Pidana (whistleblower) dan Saksi Pelaku yang bekerjasama (justice collaborators) di dalam perkara tindak pidana tertentu. SEMA merupakan aturan internal yang dapat digunakan oleh hakim apabila ketentuan mengenai perkara yang akan diputusnya belum diatur dalam peraturan perundang-perundangan. Mahkamah Agung dalam konteks ini memandang perlu membuat landasan pemecahan untuk adanya kesamaan pendapat dalam penyelesaian perkara yang sama. ${ }^{18}$

Keberlakuan SEMA ini hanya terbatas di pengadilan, sehingga untuk penegakan hukum yang lain masih belum ada peraturan perundang-undangan yang mengatur secara rinci mengenai pelindungan bagi justice collaborator. Padahal persamaan persepsi antara penegak hukum agar tidak terjadi tumpang tindih merupakan hal yang penting, sehingga pelindungan terhadap justice collaborator terealisasi secara optimal.

${ }^{17}$ Ibid, hlm. 61.

${ }^{18}$ Ahmad Yunus, "Penetapan Pelaku Tindak Pidana Korupsi Sebagai Justice Collaborator Dalam Praktik", Simbur Cahaya Vol. 24 No. 2, Mei 2017, hlm. 4765 
Sehubungan dengan penegak hukum yang lain, telah disepakati Peraturan Bersama antara Menteri Hukum dan HAM, Jaksa Agung, Kapolri, KPK dan Ketua LPSK Nomor: M.HH-11.HM.03.02. th. 2011 Nomor: PER-045/A/JA/12/2011, Nomor: 1 Tahun 2011, Nomor: KEPB-02/01-55/12/2011, Nomor: 4 Tahun 2011 tentang Pelindungan Bagi Pelapor, Saksi Pelapor dan Saksi Pelaku yang Bekerjasama, dibentuk untuk mengatur persamaan persepsi. Ada 4 hal pokok yang diatur, yaitu pelindungan fisik dan psikis, pelindungan hukum, penanganan secara khusus, memperoleh penghargaan dan semua hak tersebut dapat didapatkan apabila mendapatkan persetujuan dari penegak hukum.

Meskipun peraturan bersama ini memiliki kekuatan hukum yang mengikat bagi para pihak yang terkait, namun kedudukannya tidak sejajar atau tidak lebih tinggi dari peraturan perundang-undangan maka pelindungan mengenai justice collaborator perlu dimasukkan kedalam undang-undang yang kedudukannya lebih tinggi dibandingkan dengan peraturan bersama ini. Disamping itu menempatkan pelindungan terhadap justice collaborator ke dalam revisi KUHAP merupakan penerapan dari salah satu tujuan dari hukum pidana formil yaitu untuk melindungi hak-hak dan kemerdekaan orang serta warga negara.

\section{Model Pelindungan Hukum Terhadap Justice Collaborator dalam Penanganan Tindak Pidana Korupsi di Indonesia}

Persoalan yang krusial mengenai lembaga yang paling tepat berwenang menangani dan memberikan pelindungan terhadap justice collaborator perlu mendapat perhatian. Hal ini berhubungan erat dengan proses penanganan dari tahap laporan sampai ke pelindungan yang akan diberikan kepada seorang justice collaborator agar penanganannya lebih tepat, cepat, efektif dan efisien. Besarnya kemungkinan resiko yang didapat oleh justice collaborator, maka diperlukan pelindungan dan jaminan keamanan atas informasi yang diberikan. Sehingga perlu adanya persamaan persepsi melalui mekanisme koordinasi antar lembaga yang berwenang dalam penanganan tindak pidana korupsi yang melibatkan justice collaborator.

Pentingnya peran justice collaborator dalam pengungkapan tindak pidana korupsi di Indonesia memerlukan model pelindungan hukum terhadap justice collaborator yang tepat demi terciptanya pelindungan hukum terhadap justice 
collaborator. Menurut Lilik Mulyadi, model persuasif merupakan model yang bersifat menyeluruh terhadap pelindungan kepada justice collaborator yang melibatkan komponen Sistem Peradilan Pidana yaitu Kepolisian, Kejaksaaan, Pengadilan dan Lembaga Pemasyarakatan dan KPK untuk perkara korupsi. ${ }^{19}$ Model persuasif ini merupakan salah satu model pelindungan hukum dalam upaya memberikan pelindungan terhadap justice collaborator. Dengan model persuasif ini maka semua komponen dalam sistem peradilan pidana akan saling berkoordinasi dan apabila seorang justice collaborator telah memberikan keteranganya pada satu lembaga maka diharapkan keseluruhan komponen lembaga tersebut akan melindungi, dengan hal tersebut akan terwujud suatu pelindungan yang menyeluruh.

Secara teoritis model pelindungan persuasif ini didasari oleh alur sistem peradilan pidana yang dalam sistem peradilan pidana merupakan suatu sistem yang terdiri dari para penegak hukum yang bertujuan untuk pengendalian kejahatan. Menurut Mardjono Reksodipuro, yang dimaksud dengan sistem peradilan pidana adalah sistem pengendalian kejahatan yang terdiri dari lembaga kepolisian, kejaksaan, pengadilan dan pemasyarakatan terpidana. ${ }^{20}$

Penyelesaian perkara pidana meliputi beberapa tahap, yakni tahap penyelidikan dan penyidikan di tingkat kepolisian, tahap penuntutan di kejaksaan, tahap pemeriksaan perkara tingkat pertama di pengadilan negeri, tahap upaya hukum di pengadilan tinggi serta Mahkamah Agung serta tahap eksekusi oleh eksekutor Jaksa. Instansi yang terkait dalam proses peradilan pidana antara lain kepolisian, kejaksaan, pengadilan dan lembaga pemasyarakatan. Instansi lain di luar kepolisian dan kejaksaan, dalam kasus tertentu misalnya korupsi ada peranan KPK baik dalam penyelidikan, penuntutan, dan pemeriksaan di Pengadilan. ${ }^{21}$

Bertitik tolak dari hal tersebut, dalam Undang-Undang Nomor 31 Tahun 2014 Tentang Perubahan Atas Undang-undang Nomor 13 Tahun 2006 tentang Pelindungan Saksi dan Korban ditentukan kewenangan LPSK memberikan

\footnotetext{
${ }^{19}$ Lilik Mulyadi, Op. Cit, hlm. 205

20 Edi Setiadi dan Kristian, Sistem Peradilan Pidana Terpadu dan Sistem Penegakan Hukum di Indonesia, Prenadamedia Group, Jakarta, 2017, hlm. 18.

${ }^{21}$ Topo Santoso, Urgensi Pembenahan Pengadilan Tindak Pidana Korupsi Dalam Mewujudkan Good Governance, Karya Ilmiah, Kementerian Hukum Dan Hak Asasi Manusia R.I. Badan Pembinaan Hukum Nasional PUSLITBANG, Jakarta, 2011.
} 
rekomendasi secara tertulis kepada penuntut umum untuk dimuat di dalam tuntutannya kepada hakim. Isi rekomendasi tersebut agar majelis hakim memberikan penghargaan berupa keringanan hukuman, dan rekomendasi kepada menteri yang meyelenggarakan urusan pemerintahan di bidang hukum berupa penghargaan pembebasan bersyarat, remisi dan hak narapidana lainnya. Namun perlu diketahui, bahwa LPSK tidak masuk di dalam sistem peradilan pidana, sehingga rekomendasi yang diberikan oleh LPSK kurang dipertimbangkan para penegak hukum. Perlu persamaan pandangan antara LPSK dan para penegak hukum dalam memberikan pelindungan terhadap justice collaborator agar timbul kesepahaman antar lembaga tersebut.

Bercermin pada struktur lembaga-lembaga sistem peradilan pidana yang terbentuk sebagai suatu tata urutan mulai dari kepolisian, kejaksaan, pengadilan hingga lembaga pemasyarakatan, maka terlihat sistem peradilan pidana terangkai dalam unsur-unsur yang mempunyai peran masing-masing secara utuh. Oleh karena itu, kegiatan salah satu unsur tersebut merupakan tahapan atau bagian dari kegiatan yang utuh untuk mencapai tujuan bersama. Tujuan peradilan pidana dilaksanakan oleh beberapa lembaga yang berbeda-beda meskipun demikian lembaga yang berbeda-beda tetap mempunyai hubungan antara satu dengan lainnya dan merupakan satu kesatuan dalam mencapai tujuan akhir yang sama yaitu mencari kebenaran materiil dalam suatu tindak pidana.

Landasan yuridis model pelindungan persuasif terlihat dalam Pasal 10A Undang-Undang Nomor 31 Tahun 2014 tentang Perubahan Atas Undang-Undang Nomor 13 Tahun 2006 tentang Pelindungan Saksi dan Korban. Saksi Pelaku dapat diberikan penanganan secara khusus dalam proses pemeriksaan dan penghargaan atas kesaksian yang diberikan. ${ }^{22}$ Penanganan secara khusus sebagaimana dimaksud pada ayat (1) berupa: a. pemisahan tempat penahanan atau tempat menjalani pidana antara Saksi Pelaku dengan tersangka, terdakwa, dan/atau narapidana yang diungkap tindak pidananya; b. pemisahan pemberkasan antara berkas Saksi Pelaku dengan berkas tersangka dan terdakwa dalam proses penyidikan, dan penuntutan atas tindak pidana yang

22 Pasal 10A ayat (1) Undang-Undang Nomor 31 Tahun 2014 tentang Perubahan Atas Undang-Undang Nomor 13 Tahun 2006 tentang Pelindungan Saksi dan Korban 
diungkapkannya; dan/atau c. memberikan kesaksian di depan persidangan tanpa berhadapan langsung dengan terdakwa yang diungkap tindak pidananya. ${ }^{23}$

Ketentuan tersebut menegaskan bahwa setiap penegak hukum dalam setiap proses pemeriksaan dari tahap penyelidikan yang dilakukan oleh penyelidik sampai dengan putusan hakim berkewajiban memberikan pelindungan terhadap justice collaborator. Di sisi lain dalam Pasal 10 ayat (1) Undang-Undang Nomor 31 Tahun 2014 tentang Perubahan Atas Undang-undang Nomor 13 Tahun 2006 Tentang Pelindungan Saksi dan Korban yang menyatakan bahwa Saksi, Korban, Saksi Pelaku, dan/atau Pelapor tidak dapat dituntut secara hukum, baik pidana maupun perdata atas kesaksian dan/atau laporan yang akan, sedang, atau telah diberikannya, kecuali kesaksian atau laporan tersebut diberikan tidak dengan iktikad baik. Jelas dalam ketentuan tersebut memberikan jaminan pelindungan terhadap adanya tuntutan balik yang diajukan oleh pihak-pihak yang merasa dirugikan atas kesaksian yang diberikan oleh justice collaborator. Maka seharusnya sudah tidak ada lagi kekhawatiran justice collaborator terhadap adanya tuntutan balik terhadapnya.

Dewasa ini belum ada suatu peraturan perundang-undangan yang mengatur secara tegas dan jelas mengenai persamaan pemahaman antar lembaga mengenai pelindungan yang akan diberikan kepada justice collaborator. Kehadiran justice collaborator dalam pengungkapan tindak pidana korupsi sangat dibutuhkan oleh penegak hukum. Justice collaborator dapat melaporkan kepada LPSK, kepolisian, kejaksaan dan KPK tentang apa yang dia ketahui dalam perkara korupsi yang melibatkan dirinya.

Apabila kedepan diterapkan model persuasif yang menitikberatkan pada keterlibatan semua komponen lembaga dalam sistem peradilan pidana untuk memberikan pelindungan terhadap justice collaborator yang bersifat menyeluruh, maka antar para penegak hukum akan saling terkoordinasi. Jika seorang justice collaborator telah memberikan keteranganya pada satu lembaga maka diharapkan keseluruhan komponen lembaga tersebut akan melindungi, maka di sini akan tercipta perlindungan yang bersifat menyeluruh. Model persuasif ini akan

${ }^{23}$ Pasal 10A ayat (2) Undang-Undang Nomor 31 Tahun 2014 tentang Perubahan Atas Undang-Undang Nomor 13 Tahun 2006 tentang Pelindungan Saksi dan Korban 
memberikan kesamaan pandangan dalam mekanisme penetapan dan pelindungan terhadap justice collaborator dari seluruh aparat penegak hukum.

Penerapan model ini perlu didukung regulasi berupa peraturan perundangundangan sebagai upaya penyamaan pandangan terhadap justice collaborator. Tercapainya persamaan pandangan antara seluruh komponen lembaga dalam memberikan penanganan dan pelindungan terhadap justice collaborator akan meminimalisir singgungan maupun tumpang tindih kewenangan. Sehingga dengan adanya model persuasif ini justice collaborator akan diberikan rasa aman karena mendapatkan pelindungan yang menyeluruh, serta dari sisi lain model ini memberikan kepastian hukum terhadap seorang justice collaborator.

Penerapan model persuasif melalui pembaharuan hukum pidana formil ini dapat mewujudkan tercapainya tujuan dari hukum pidana formil dalam melindungi seorang justice collaborator sebagai manusia yang memiliki hak-hak yang harus dilindungi. Sebagaimana yang diketahui bahwa justice collaborator memiliki peran penting dalam pengungkapan suatu perkara, maka model persuasif ini menjadi suatu harapan bagi seorang justice collaborator untuk mendapatkan pelindungan dan keringanan pidana.

\section{Penutup}

Berdasarkan analisis di atas, dapat disimpulkan bahwa pelindungan terhadap justice collaborator yang saat ini diatur dalam hukum positif Indonesia baru dalam bentuk pelindungan fisik, dan psikis, penanganan khusus, pelindungan hukum dan penghargaan. Ketentuan mengenai pelindungan terhadap justice collaborator tersebut tercantum di berbagai peraturan. Belum ada peraturan yang secara khusus, jelas, dan pasti mengenai pelindungan terhadap seorang justice collaborator. Status quo memicu pelaku yang akan memberikan kesaksiannya sebagai justice collaborator untuk membongkar perkara tindak pidana korupsi enggan memberikan keterangannya karena menganggap tidak ada kepastian penghargaan dan pelindungan. Padahal untuk menjadi seorang justice collaborator menanggung resiko yang sangat besar karena telah membongkar suatu perkara yang besar seperti perkara-perkara tindak pidana korupsi. Dari sinilah diketahui betapa pentingnya pelindungan bagi seorang 
justice collaborator dalam peranannya membongkar suatu perkara tindak pidana korupsi agar seorang justice collaborator merasa terjamin dalam hal pelindungan hukum dan kepastan hukum.

Model pelindungan hukum terhadap justice collaborator dalam penanganan tindak pidana korupsi di Indonesia dapat menggunakan model pelindungan persuasif. Model persuasif ini bersifat menyeluruh terhadap pelindungan kepada justice collaborator yang melibatkan semua komponen penegak hukum yang memiliki kewenangan penanganan tindak pidana korupsi. Dengan menggunakan model persuasif ini antar komponen lembaga saling berkoordinasi satu sama lainnya, sehingga apabila seorang justice collaborator telah memberikan keteranganya pada satu lembaga maka diharapkan keseluruhan komponen lembaga tersebut akan melindungi.

\section{Daftar Pustaka}

\section{Buku}

Mulyadi, Lilik, Whistleblower dan Justice Collaborator Dalam Upaya Penanggulangan Organized Crime, PT Alumni, Bandung, 2015.

Marzuki, Peter Mahmud, Penelitian Hukum Edisi Revisi, Prenadamedia Group, Jakarta, 2014.

Harahap, Yahya, Pembahasan, Permasalahan dan Penerapan KUHAP, Penyidikan dan Penuntutan, Edisi Kedua, Sinar Grafika, Jakarta, 2012.

Setiadi Edi, Sistem Peradilan Pidana Terpadu dan Sistem Penegakan Hukum di Indonesia, Prenadamedia Group, Jakarta, 2017.

Sulistia, Teguh, Hukum Pidana Horizon Pasca Reformasi, PT. Raja Grafindo Persada, Jakarta, 2011.

Syamsuddin, Aziz, Tindak Pidana Khusus, Sinar Grafika, Jakarta, 2011.

\section{Jurnal}

Achmad Saifudin Firdaus, "Kedudukan Terdakwa Sebagai Saksi (Saksi Mahkota) Terhadap Terdakwa Lain Dalam Tinjauan Hukum Acara Pidana, Lex Jurnalica Vol. 12 No. 3, Desember 2015.

Ahmad Yunus, "Penetapan Pelaku Tindak Pidana Korupsi Sebagai Justice Collaborator Dalam Praktek", Simbur Cahaya, Vol. 24 No. 2, Mei 2017.

Hariman Satria, "Menakar Pelindungan Justice Collaborator", Jurnal Konstitusi, Vol. 13 No. 2, Juni 2016. 
Ifrani, “Tindak Pidana Korupsi Sebagai Kejahatan Luar Biasa”, $A l$ 'Adl, Vol. IX No. 3, Desember 2007.

Muhammad Iqbal Lubis, "Pelindungan Hukum Terhadap Justice Collaborator Dalam Hukum Pidana di Indonesia : Analisis Putusan Mahkamah Agung No. 2223K/Pid.Sus/2012", USU Law Journal, Vol. 7 No. 3, Juni 2019.

\section{Karya Ilmiah}

Topo Santoso, "Urgensi Pembenahan Pengadilan Tindak Pidana Korupsi Dalam Mewujudkan Good Governance", Karya Ilmiah, Kementerian Hukum Dan Hak Asasi Manusia R.I. Badan Pembinaan Hukum Nasional PUSLITBANG, Jakarta, 2011

\section{Internet}

https:/ / business-law.binus.ac.id/2018/02/14/justice-collaborator-dan-pelindunganhukumnya, diakses tanggal 19 Januari 2020

\section{Peraturan Perundang-Undangan}

Undang-Undang Nomor 31 Tahun 1999 kini telah diubah menjadi UndangUndang Nomor 20 Tahun 2001 tentang Pemberantasan Tindak Pidana Korupsi, Lembaran Negara Republik Indonesia Tahun 1981 Nomor 76, Tambahan Lembaran Negara Republik Indonesia Nomor 4150

Undang-Undang Nomor 39 Tahun 1999 tentang Hak Asasi Manusia, Lembaran Negara Republik Indonesia Tahun 1999 Nomor 165, Tambahan Lembaran Negara Republik Indonesia Nomor 3886

Undang-Undang Nomor 31 Tahun 2014 tentang Perubahan Atas UndangUndang Nomor 13 Tahun 2006 tentang Pelindungan Saksi dan Korban, Lembaran Negara Republik Indonesia Tahun 2006 Nomor 64, Tambahan Lembaran Negara Republik Indonesia Nomor 5602

Peraturan Pemerintah Nomor 71 Tahun 2000 tentang Tata Cara Pelaksanaan Peran Serta Masyarakat dan Pemberian Penghargaan Dalam Pencegahan dan Pemberantasan Tindak Pidana Korupsi.

\section{Peraturan Lembaga}

Surat Edaran Mahkamah Agung Nomor 04 Tahun 2011 tentang Perlakuan terhadap Pelapor Tindak Pidana (whistleblower) dan Saksi Pelaku yang Bekerja Sama (justice collaborator) di Dalam Perkara Tindak Pidana Tertentu 